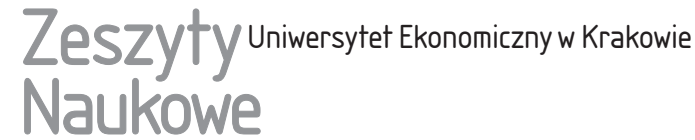

\author{
Zoran Kalinić \\ Vladimir Ranković \\ Ljubina Kalinić
}

\section{Challenges in Cross-border E-commerce in the European Union*}

\begin{abstract}
Electronic commerce (e-commerce), usually defined as trade conducted over computer networks, has attracted considerable attention for decades. The paper presents the current state of development of retail e-commerce in the European Union, with particular analysis of development of cross-border online trade. Despite its considerable effort, the European Union is still far from an integrated market, as online shoppers still prefer domestic markets to other EU markets. The focus of the paper is on the main challenges of cross-border B2C e-commerce, i.e. online purchases of individual EU consumers made in other EU countries. Some important barriers to the establishment of a fully-integrated digital market in the European Union, including issues related to logistics and delivery, language and location, legal and tax regulation and geo-blocking, are addressed in detail. Finally, ongoing activities to reduce the influence of these obstacles are presented.
\end{abstract}

\footnotetext{
Zoran Kalinić, University of Kragujevac, Faculty of Economics, Liceja Knezevine Srbije 3, 34000 Kragujevac, Serbia, e-mail: zkalinic@kg.ac.rs

Vladimir Ranković, University of Kragujevac, Faculty of Economics, Liceja Knezevine Srbije 3, 34000 Kragujevac, Serbia, e-mail: vladar@kg.ac.rs

Ljubina Kalinić, Direktna Banka a.d., Kragujevac, Serbia, e-mail: ljubina.kalinic@gmail.com

* The publication was supported by the Ministry of Education, Science and Technological Development of the Republic of Serbia, Grant III-44010.
} 
Keywords: electronic commerce, cross-border e-commerce, barriers, Digital Single Market. JEL Classification: L81, M31.

\section{Introduction}

Electronic commerce (e-commerce), usually defined as trade conducted over computer networks, has attracted considerable attention for decades. Ecommerce Europe (2016a) estimates that almost half of the global population today uses the Internet, while almost every fourth person shops online. E-commerce still has high growth rates $-23 \%$ in 2017, as estimated by eMarketer (2017). In Europe, about three quarters of inhabitants use the Internet, while about $45 \%$ shop online, generating more than 4 billion shipments per year (Ecommerce Europe 2016a). The European market is mostly well-developed and mature, and at about $15 \%$ annually, its growth rates are lower (Ecommerce Europe 2017). The leader is the United Kingdom, with a full third of the European e-commerce market, and higher turnover than the next three countries - Germany, France and Russia combined (Ecommerce Europe 2016b).

This paper focuses on cross-border B2C e-commerce - particularly, online purchases made by individual consumers in countries other than their own. Cross-border online trade is often seen as a significant factor in economic growth. PayPal research (2016) found better prices, access to items not available in one's own country and wider availability of different products and styles to be the top reasons people shop online abroad.

B. van Hell, V. Lukic and E. Leeuwis (2014) estimate that cross-border e-commerce currently accounts for about $10 \%$ of total e-commerce volume. Cross-border e-commerce is now developing faster than domestic e-commerce, annual growth of cross-border online trade for the period 2017-2022 is estimated to come in at $17 \%$, while the annual growth rate of total e-commerce in the same period is estimated at 12\% (Martin 2017). China is the leader in cross-border e-commerce, as its retail exports account for $37 \%$ of global Chinese market share, which is the highest share in the world.

\section{The State of Cross-border E-commerce in the EU Today}

The goal of the Digital Single Market (DSM) is to ensure the free movement of people, services and capital, irrespective of their nationality or place of residence (European Commission 2017). Unfortunately, the European e-commerce market is not completely seamless (Duch-Brown \& Cardona 2016), i.e. the EU has yet to evolve into a truly single market. The EU and the EC are especially interested 
in promoting cross-border e-trade as one of the most important elements in their DSM strategy (Valarezo et al. 2017).

The Digital Agenda for Europe (European Commission 2010) set two main e-commerce targets for 2015: for 50\% of citizens to be shopping online and $20 \%$ of citizens to be doing cross-border shopping. As Figure 1 shows (Eurostat 2018), the first target was reached in 2014, a year prior to the plan, while the second target was reached exactly as planned. Figure 1 also shows steady growth in European e-buyers, both domestic and cross-border. However, there are significant differences in these percentages across countries.

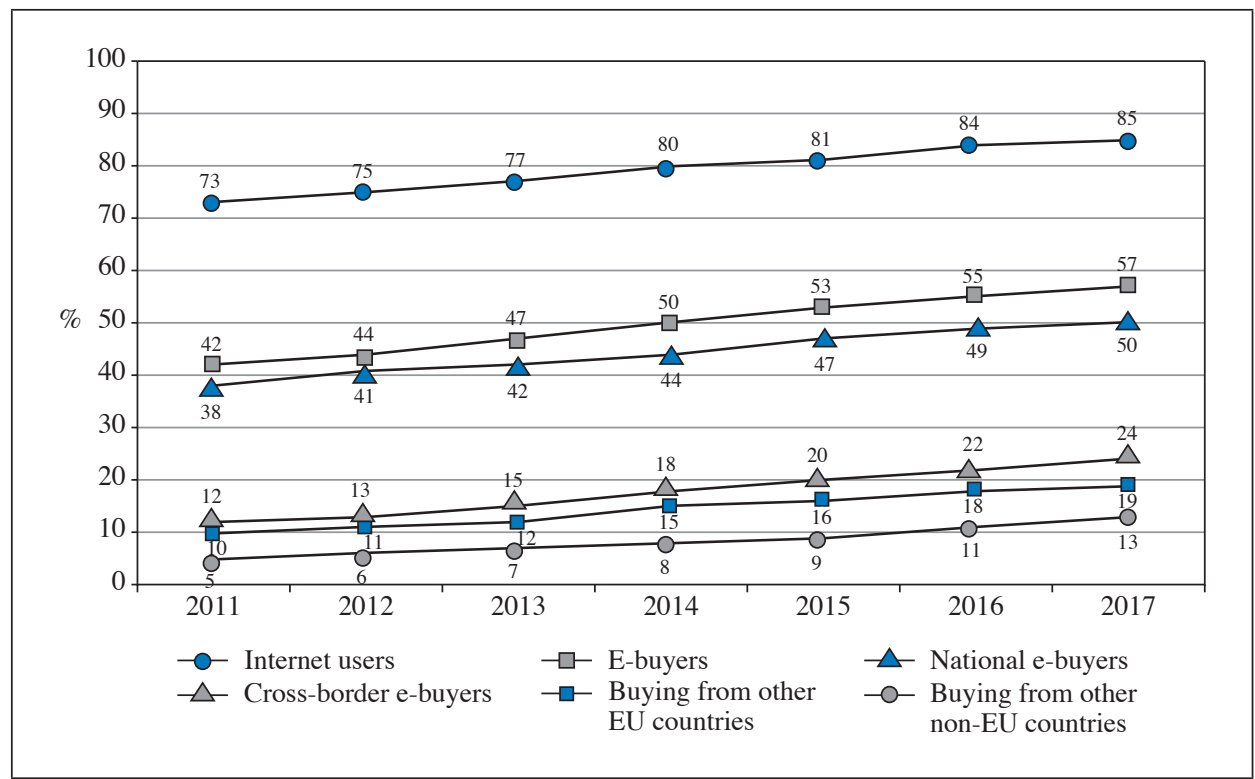

Fig. 1. Internet Users and e-Buyers in the European Union (as a \% of Total Population Aged 16-74)

Source: Eurostat (2018).

The highest percentage of e-buyers is in the UK, where about $82 \%$ of citizens shop online (Fig. 2), while the lowest result was recorded in Romania, where only $16 \%$ of inhabitants bought something over the internet in the past year. For our study, cross-border e-buyers are the most relevant group: the leading EU countries in cross-border e-commerce are Luxembourg, Malta and Austria, while Poland and Romania round out the bottom of the list. This data is in line with the recent PayPal study (2016), which reported Japan (95\%) and Poland as the countries with highest percentages of consumers shopping only on their national online markets. 


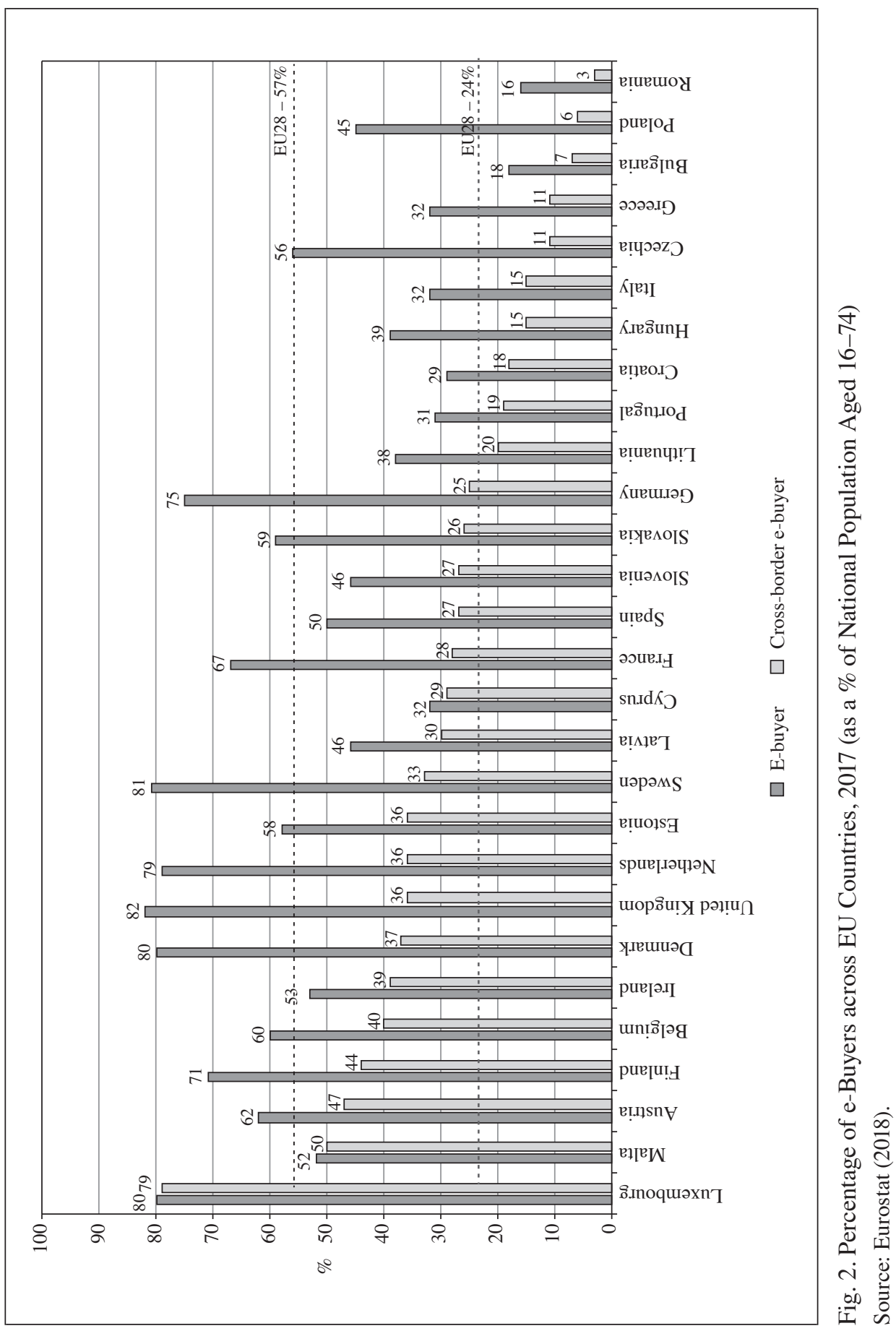


PayPal research (2016) confirmed that smaller European countries have more open attitudes to cross-border e-commerce, while larger European countries and some Asian countries prefer "global" stores like Amazon and eBay. China (21\%) is generally the most popular destination for cross-border e-commerce, followed by the US (17\%) and the UK (13\%) (PayPal 2016). The two by far most important EU cross-border markets - the biggest exporters, that is - are the United Kingdom and Germany (GfK 2015). For example, when online shopping abroad, Polish customers usually buy from the US (32.2\%), Germany (32.1\%) and China (24\%) (Paypers 2014). Most of them shop cross-border due to a lack of product selection domestically (78\%) and lower prices (50\%) (Paypers 2014).

\section{Obstacles to a Truly Single Digital Market in the EU}

Slower-than-expected growth of cross-border trade is caused by many factors, a which have been documented by several studies. For example, a recent Ecommerce Europe (2016b) study identified the main barriers to a fully-integrated digital internal EU market, including differing EU legal frameworks, complicated and expensive taxation (VAT) systems and logistics and distribution issues. These were likewise confirmed by A. Coad and N. Duch-Brown (2017). Likewise, research presented by D. Martin (2017) found logistics and delivery (43\% of respondents) and compliance with local regulations (39\%) to be the main obstacles to cross-border e-commerce.

According to an EU study on e-commerce (GfK 2015), consumers report six main barriers to cross-border shopping: high delivery costs, high return shipping costs and long delivery times, problems with consumer rights, complaint handling and geo-blocking. A recent PayPal study reached the same conclusions (PayPal 2016).

A study carried out by GfK (2015) together with the European Commission identified country size, language and geographical proximity as the three main factors driving the flow of cross-border e-commerce. The size of a Member State and its online domestic market is often determined by its population size and Gross Domestic Product (GDP). The cross-border flow of goods, offline services and digital content predominantly moves from larger Member States towards smaller ones like Luxembourg and Malta. One of the reasons for this is that smaller countries have small internal markets, with a limited choice and offer. Further, lower competition in these small internal markets may lead to some forms of local monopoly and higher prices, driving consumers to look for more competitive prices abroad. On the other hand, between large Member States, relatively little cross-border e-commerce activities occur, confirming the idea that size is one of 
the most important drivers of cross-border e-commerce (GfK 2015). For example, Germany and France share the same border, but the percentage of cross-border online purchases between them is rather low, due mostly to the language barrier and their large internal markets.

\section{Logistics and Delivery Issues}

E-commerce in general has caused significant changes in the postal and parcel markets. While improvements have been made, especially on domestic markets, $33 \%$ of companies selling abroad still perceive logistics and distribution as a significant barrier. Several studies confirm that long delivery times and high delivery costs are one of the main barriers to cross-border e-commerce, making logistics a crucial aspect of an e-commerce initiative (Giuffrida et al. 2017). Shorter delivery times will lead to greater satisfaction on the part of consumers and customer retention for enterprise. Proximity was confirmed as an important predictor of cross-border purchases in other cases - France exports mostly to Belgium, Luxembourg, Italy and Spain, while Sweden exports to Denmark and Finland and Italy exports to Malta and Croatia, etc. (GfK 2015). To address this skewing, it is necessary to harmonise the currently fragmented market by inducing collaboration among all stakeholders (regulators, online merchants, delivery service providers, solution providers, etc.) and use open and interoperable standards (Ecommerce Europe 2016c).

Another important objective laid down in the EU's Digital Single Market strategy is to make parcel delivery more affordable and efficient. To this end, in March 2018 the regulations intended to make cross-border parcel delivery more affordable were adopted by the European Parliament and will be fully applicable in 2019. Unfortunately, in the EU e-retail market, although there are some options, cross-border e-commerce with express delivery is currently still in a nascent stage, mainly due to the still very high costs (EUR 2016). In the context of shipping costs as one of the key barriers to cross-border e-commerce, it should be stressed that more and more sellers, particularly from China, are offering free shipping, even internationally. A recent International Post Corporation (2018) survey reported that $62 \%$ of respondents had received free shipping.

\section{Language and Location}

A common language between two Member States can facilitate online transactions and eliminate costs associated with translation. This is significant given that five of the six top cross-border e-commerce countries (Luxembourg, Malta, Austria, Belgium, and Ireland) share a common language with at least one neighbouring Member State. For example, Ireland, Austria and Belgium, despite their medium-sized populations and GDPs, are among the EU leaders in cross-border 
online purchases. The reasons for that are their geographical locations, i.e. proximity of larger markets and the official languages spoken i.e. a shared language with that neighbouring market. Language is the more important of these two factors (Martin 2017). For proof of this, consider Malta or Cyprus, whose main source for cross-border e-commerce is the United Kingdom, despite the geographical distance between them. English is the official language in Ireland, so most Irish respondents (61\%) report making cross-border online purchases or accessing digital content from the UK (GfK 2015). They also share the same border. The same is true for Luxembourg and Austria in relation to Germany, and for Belgium in relation to France or the Netherlands. English is by far the most popular and widespread second language in the EU (the Special Eurobarometer 3863 reports that 38\% of EU citizens speak English fluently enough to have a conversation), which gives the UK a significant language advantage in cross-border e-commerce, despite its different currency. On the other hand, German, French and Italian e-retailers need to make significant investments in translating their websites into English.

Interestingly, unlike the UK and Germany, France and Italy - and their important EU economies - play a relatively small role as cross-border exporters. One of the reasons may be that German online retailers invest more heavily in website translations (compared to their French and Italian counterparts), which in many cases eliminates the language barrier and provides them with greater opportunities to generate sales. So, the lack of a common language appears to be a strong barrier to cross-border e-commerce and vice versa. E-retailers should therefore be advised and encouraged to translate their online offers, as a priority, into English and other major EU28 languages (GfK 2015).

Due to the language barrier, for successful entrance to cross-border market, it is of the utmost importance that a business have a localised web-shop - that is, a web store in the local language, with prices in the local currency and, if possible, preferred local payment methods, which also significantly improves one's local search engine ranking. Another aspect of location are different size scales in different countries, for example, in the US and the countries of Europe. However, even within Europe, there are differences: an item labelled 38 in France is the equivalent of a 42 in Italy (Salesupply 2016). Of course, this problem is easily solved - the web-store merely needs to post conversion tables with its offer.

\section{Legal and Tax Issues}

Ecommerce Europe (2016c) reported overly restrictive regulations in other Member States as the main reason for not selling abroad. Dealing with 28 different sets of rules for data protection, privacy, consumer and contract laws is quite challenging and expensive and prompts the need for a single rule to achieve a Single Digital Market. These are some of the main reasons why most of the companies 
selling cross-border have expanded sales on only a few neighbouring markets. An European Commission (2015) study reports that $57 \%$ of the companies would either start or increase their online sales to other EU countries, if the same rules for e-commerce were applied across all EU members.

The same goes for different taxation systems, VAT rates and/or customs, which were recognised as a significant barrier by $48 \%$ of European companies (Ecommerce Europe 2016c). VAT-related accounting and administrative costs, difficult VAT registration and declaration procedures and general unawareness of VAT rules are considered the main problems. At the moment, only large online retailers from the larger Member States can afford to break down the existing cross-border e-commerce barriers. In December 2017, the EU adopted a series of measures to improve and simplify how VAT works for online companies in the EU, which will progressively come into force by 2021 and ensure that VAT is paid in the Member State of the final consumer.

\section{Geo-blocking}

Geo-blocking is the practice of online sellers deliberately blocking consumers from other countries from accessing their web shops (Cardona 2016). Using various geo-location tools, sellers may identify the physical location of their visitors through their IP addresses, physical mailing addresses or card payment details. Geo-blocking between EU countries is recognised as a barrier to a truly single market in the EU, and its elimination was one of the policy targets in the EU Digital Single Market Strategy (Cardona 2016).

Not all geo-blocking is unethical. In some cases, it can be legitimate when it helps web shops comply with trade restrictions in national legislation. For example, online cross-border trade may be illegal for some services, like some types of copyright-protected digital media content or gambling services (Cardona 2016). Also, sellers may have good reasons to block cross-border sales, as they may be too costly for sellers in terms of administrative costs and compliance with tax and other regulations in foreign markets. Sometimes producers may restrict distributors from selling in different countries by means of exclusive territory contracts or selective distribution agreements (Coad \& Duch-Brown 2017). On the other hand, sellers can unjustifiably offer different prices and sales conditions for a given product or service based on the consumer's geographic location, thus discriminating against customers from other Member States.

A recent Eurobarometer (2015) study reports that one in ten consumers purchasing online from another EU country reported that the seller refused to deliver to their country. Also, $8 \%$ of customers were redirected from an original website to a website in their country where the prices were different. Meanwhile, $5 \%$ of customers were denied the ability to pay from their country. Likewise, in 
an EU-wide online mystery shopping survey conducted in 2015 (Cardona 2016), $8.4 \%$ of the shopping attempts (weighted according to the traffic volume of the website) were blocked at the first stage, i.e. shoppers could not access the website from their own country or they were redirected to a different website. Also, when accessing from another country, not all mystery shoppers were able to find the same product offer as domestic shoppers. In some cases, they were not able to select their country as a destination in the checkout process, or the website did not accept their payment details, such as their credit cards. Although the average prices in the survey were higher for foreign than domestic shoppers, in some cases, the opposite trend was observed (higher prices for domestic buyers), probably due to monopoly on the local market or attempted tax evasion. Of course, the survey showed that not all countries were treated the same. While buyers from Austria, the UK and Ireland have the highest success rates for making it to the order button, shoppers from Slovakia, Croatia and Malta experienced just the opposite fate.

In years past, the EC has worked hard to eliminate geo-blocking within the EU. Any unjustified discrimination against consumers, related to the prices or contracting conditions, due to place of residence or nationality, is considered to constitute a serious threat to the Digital Single Market, and therefore should be eliminated (Valarezo et al. 2017). In order to realise the full potential of the internal market, the European Parliament (2018) on February 2018 adopted a Regulation addressing unjustified geo-blocking and other forms of discrimination based on customers' nationality, place of residence or place of establishment by removing certain barriers to the functioning of the internal EU market. Under the terms of the Regulation, starting in December 2018, it is prohibited to treat customers differently, unless doing so is justified under EU or national laws and regulations.

\section{Global Marketplaces}

As reputable global platforms, global marketplaces are the most popular choice for cross-border buyers (Garcia 2018). So, shoppers prefer to go to Amazon's web-store rather than take a chance on an unfamiliar retailer or website. Xue et al. (2016) suggest that high-tech cross-border e-commerce platforms with integrated services (payment, logistics, credit, product quality insurance) are the best means to developing cross-border e-trade. A recent International Post Corporation (2018) survey reported Amazon as the first marketplace choice (25\% of cross-border digital buyers globally), followed by eBay (18\%) and AliExpress (14\%). 56\% of all items sold cross-border were actually bought on Alibaba, Amazon or eBay, while $34 \%$ of parcels were purchased from China, making that country the first foreign source e-market for the majority of EU countries (exceptions are Ireland, Austria, Luxembourg, Cyprus, Belgium, for the reasons already explained). D. Martin 
(2017) estimates that by $2020,39 \%$ of the world's e-commerce market will be controlled by marketplaces.

At the moment, 53\% of cross-border sellers in the US already use online marketplaces (Martin 2017), which owe their popularity to the perceived level of security and usability for all parties involved. They offer a cheaper and less risky way to engage in cross-border online trade for all interested merchants by taking away major barriers of cross-border sales, including regulation, location, logistics and payments (Martin 2017). The existence of pan-European marketplaces like Amazon, eBay or Aliexpress would certainly boost EU cross-border e-commerce, as well as open the EU online market to the rest of the world.

\section{Conclusions}

The results of this study indicate that the merchants' preferred strategy of internationalisation is to sell to consumers abroad directly from the merchant's country of origin, and that other strategies, including selling through a local branch or through a presence on the marketplaces established abroad, are significantly less popular (Ecommerce Europe 2016c). This further attests to the need to complete a bona fide Digital Single Market as soon as possible.

From previous analysis, it is obvious that the EU is still far from an integrated digital market, but in the last few months some important steps and decisions have been made by the EC and European Parliament. In future, factors including the introduction of the PSD2 Directive and GDPR, Brexit and Trump's isolationism may have a significant, though negative, influence on cross-border e-commerce development.

\section{Bibliography}

Cardona M. (2016), Geo-blocking in Cross-border e-Commerce in the EU Digital Single Market, Institute for Prospective Technological Studies, Joint Research Centre. Digital Economy Working Paper, 2016/04, https://ec.europa.eu/jrc/sites/jrcsh/files/ JRC101438.pdf (accessed: 6.03.2018).

Coad A., Duch-Brown N. (2017), Barriers to European Cross-border eCommerce, JRC Digital Economy Working Paper 2017-03, JRC105675, https://ec.europa.eu/jrc/sites/ jrcsh/files/jrc105675.pdf (accessed: 6.03.2018).

Duch-Brown N., Cardona M. (2016), Delivery Costs and Cross-border e-Commerce in the EU Digital Single Market, Institute for Prospective Technological Studies, Joint Research Centre. Digital Economy Working Paper 2016/03. JRC101030, https:/ec. europa.eu/jrc/sites/jrcsh/files/JRC101030.pdf (accessed: 6.03.2018).

Ecommerce Europe (2016a), Global E-commerce Report 2016, https://www.ecommerceeurope.eu/research/ecommerce-europe-reports (accessed: 1.03.2018). 
Ecommerce Europe (2016b), European E-commerce Report 2016, https://www. ecommerce-europe.eu/research/ecommerce-europe-reports (accessed: 1.03.2018).

Ecommerce Europe (2016c), Cross-border E-commerce Barometer, https://www. ecommerce-europe.eu/publication/cross-border-e-commerce-barometer-2016/ (accessed: 1.03.2018).

Ecommerce Europe (2017), European Ecommerce Report 2017, https://www.ecommerceeurope.eu/research/ecommerce-europe-reports (accessed: 1.03.2018).

eMarketer (2016), Worldwide Retail Ecommerce Sales Will Reach \$1.915 Trillion This Year, https://www.emarketer.com/Article/Worldwide-Retail-Ecommerce-Sales-WillReach-1915-Trillion-This-Year/1014369 (accessed: 3.03.2018).

eMarketer (2017), E-commerce Will Pass a Key Milestone This Year, https://retail.emarketer. com/article/ecommerce-will-pass-key-milestone-this-year/596e4c8cebd40005284d5ccd (accessed: 3.03.2018).

EUR (2016), The Value of Express Delivery Services for Cross-border E-commerce in European Union Markets, Erasmus University Rotterdam - Economic Institute Report EI2016-12, https://repub.eur.nl/pub/79921/EI2016-12.pdf (accessed: 6.03.2018).

Eurobarometer (2015), Consumer Attitudes towards Cross-border Trade and Consumer Protection, Flash Eurobarometer no. 397.

European Commission (2010), A Digital Agenda for Europe. Communication from the Commission, COM (2010) 245 final.

European Commission (2015), Why We Need a Digital Single Market, https://ec.europa.eu/ commission/sites/beta-political/files/dsm-factsheet_en.pdf (accessed: 8.03.2018).

European Commission (2017), E-commerce Statistics for Individuals, http://ec.europa. eu/eurostat/statistics-explained/index.php/E-commerce_statistics_for_individuals (accessed: 6.03.2018).

European Parliament (2018), Regulation (EU) 2018/302 of the European Parliament and of the Council of 28 February 2018 on addressing unjustified geo-blocking and other forms of discrimination based on customers' nationality, place of residence or place of establishment within the internal market, Official Journal of the EU, vol. 61.

Eurostat (2018), Complete Database. Science, Technology, Digital Society, http://ec. europa.eu/eurostat/data/database (accessed: 1.03.2018).

Garcia K. (2018), Cross-border Buyers Favor Global Platforms, eMarketer, https:// retail.emarketer.com/article/cross-border-buyers-favor-global-platforms/5a78c8f9eb$\mathrm{d} 4000744 \mathrm{ae} 4104$ ?ecid=NL1014 (accessed: 4.03.2018).

GfK (2015), Provision of Two Online Consumer Surveys as Support and Evidence Base to a Commission Study: Identifying the Main Cross-border Obstacles to the Digital Single Market and Where They Matter Most, Final report, https://publications. europa.eu/en/publication-detail/-/publication/1ee5f89c-812c-11e5-b8b7-01aa75ed71a1/ language-en (accessed: 15.03.2018).

Giuffrida M., Mangiaracina R., Perego A., Tumino A. (2017), Cross-border B2C E-commerce to Greater China and the Role of Logistics: A Literature Review, International Journal of Physical Distribution \& Logistics Management, vol. 47, no. 9.

Hell B. van, Lukic V., Leeuwis E. (2014), Cross-border E-commerce Makes the World Flatter, Boston Cons. Group, http://www.bcgperspectives.com/content/articles/ transportation_travel_tourism_retail_cross_border_ecommerce_makes_world_ flatter/ (accessed: 6.03.2018). 
International Post Corporation (2018), Cross-border E-commerce Shopper Survey 2017, https://www.ipc.be/en/knowledge-centre/e-commerce/cross-border-e-commerceshopper-survey (accessed: 12.03.2018).

Martin, D. (2017), Key Business Drivers and Opportunities in Cross-border Ecommerce 2017: Expanding Internationally in an Increasingly Competitive Market, Payvision, https://www.payvision.com/key-business-drivers-2017 (accessed: 8.03.2018).

PayPal (2016), PayPal Cross-border Consumer Research 2016, https://www.ipsos. $\mathrm{com} /$ sites/default/files/migrations/en-uk/files/Assets/Docs/Polls/ipsos-paypal-crossborder-consumer-research-2016.pdf (accessed: 8.03.2018).

Paypers (2014), Cross-border E-commerce Report, Critical Facts and Insights for International Expansion - Poland, https://www.thepaypers.com/reports/cross-borderecommerce-country-reports/r753142 (accessed: 8.03.2018).

Salesupply (2016), How to Boost Conversion for Cross-border Webshops, https://www. ingenico.com/binaries/content/assets/epayments/resources/white-paper-ingenicoepayments---how-to-boost-conversion-for-cross-border-webshops.pdf (accessed: 12.03.2018).

Valarezo A., Pérez-Amaral T., Garín-Muñoz T., García I.H., López R. (2017), Drivers and Barriers to Cross-border E-commerce: Evidence from Spanish Household Behavior, https://doi.org/10.2139/ssrn.3099541.

Xue Wanxin X., Dandan L., Yilei P. (2016), The Development and Current of Cross-border E-commerce, WHICEB 2016 Proceedings, no. 53.

\section{Wyzwania transgranicznego handlu elektronicznego w Unii Europejskiej}

(Streszczenie)

Handel elektroniczny (e-commerce), określany jako handel prowadzony za pośrednictwem sieci komputerowych, od wielu lat jest przedmiotem szczególnego zainteresowania. W artykule przedstawiono stan rozwoju elektronicznego handlu detalicznego w Unii Europejskiej, ze szczególnym uwzględnieniem internetowego handlu transgranicznego. Pomimo podejmowanych wysiłków handel elektroniczny w Unii Europejskiej nie ma charakteru jednolitego rynku. Konsumenci preferują zakupy online na rynkach krajowych. W artykule skupiono się na głównych wyzwaniach związanych z transgranicznym handlem elektronicznym B2C (business to consumer), $\mathrm{tj}$. zakupach online indywidualnych konsumentów dokonywanych w innych krajach UE. Szczegółowo przeanalizowano wybrane istotne ograniczenia w tworzeniu w pełni zintegrowanego rynku handlu elektronicznego w Unii Europejskiej, związane z logistyką i dostawą, językiem i lokalizacją, przepisami prawnymi i podatkowymi oraz tzw. geoblokowaniem. Wskazano również działania podejmowane w celu zmniejszenia wpływu wymienionych ograniczeń.

Słowa kluczowe: handel elektroniczny, transgraniczny handel elektroniczny, bariery handlu elektronicznego, jednolity rynek cyfrowy. 